\title{
Evaluation of the Non-destructive Method Efficiency of Estimating Nitrogen Content in Jambu Plants Grown in Hydroponic System
}

Italo Marlone Gomes Sampaio (Correspondins author)

Soil Science department, Institute of Agrarian Sciences, Federal Rural University of Amazon, CEP. 066.077-830. Belém, Pará, Brasil. E-mail: italofito@ gmail.com

\section{Mário Lopes da Silva Júnior}

Soil Science department, Institute of Agrarian Sciences, Federal Rural University of Amazon, CEP. 066.077-830. Belém, Pará, Brasil. E-mail: mario.silva_junior@yahoo.com.br

\section{Erika da Silva Chagas}

Soil Science department, Institute of Agrarian Sciences, Federal Rural University of Amazon, CEP. 066.077-830. Belém, Pará, Brasil. E-mail: erikachagas8@gmail.com

\section{Ricardo Falesi Palha de Moraes Bittencourt}

Soil Science department, Institute of Agrarian Sciences, Federal Rural University of Amazon, CEP. 066.077-830. Belém, Pará, Brasil. E-mail: ricardofalesibitten@gmail.com

\section{Vivian Christine Nascimento Costa}

Soil Science department, Institute of Agrarian Sciences, Federal Rural University of Amazon, CEP. 066.077-830. Belém, Pará, Brasil. E-mail: vivian.costa.1993@gmail.com

\section{Dandara Lima de Souza}

Soil Science department, Institute of Agrarian Sciences, Federal Rural University of Amazon, CEP. 066.077-830. Belém, Pará, Brasil. E-mail: dandaralima23@gmail.com 
E-mail: aleksandersantos05@gmail.com

\author{
Bruno José Brito Teixeira \\ Federal University of Pará, CEP - 66.075-110. Belém, Pará, Brasil. \\ E-mail: bjbteixeira@gmail.com
}

Received: Feb. 3, 2020

doi:10.5296/jas.v8i2.16380
Accepted: Mar. 4, 2020

Published: Mar. 16, 2020

URL: https://doi.org/10.5296/jas.v8i2.16380

\begin{abstract}
Jambu is considered a leafy vegetable with expressive relevance in the regions that compose the Brazilian Amazon. However, there are challenges regarding its cultivation, particularly for the nutritional management, since there is little technical information that allows an increase in the efficiency of its production. In this sense, nitrogen $(\mathrm{N})$ gains prominence, since it is related to the increased yield and quality of leafy vegetables, therefore its monitoring of $\mathrm{N}$ content in plants is necessary. The objective of this study was to evaluate the efficiency of using the SPAD index to estimate the $\mathrm{N}$ content of jambu leaves, total chlorophyll concentration, as well as its relationship with dry mass accumulation due to the increase of nitrogen concentration in the nutrient solution. The design used was completely randomized with eight replications. The treatments were six nitrogen concentrations in the nutrient solution $\left(11,13,15,17,19\right.$ and $\left.21 \mathrm{mmol} \mathrm{L}^{-1}\right)$. After 21 days of transplantation, the SPAD index was measured. Then, these plants were collected to quantify the total chlorophyll, dry mass and nitrogen content. In general, the variables were explained by increasing linear models. There was a positive correlation between the SPAD index and the other characteristics evaluated. Based on the results, the best response at the concentration of 21 mmol L ${ }^{-1}$ in the nutrient solution stands out. In addition, the SPAD index has potential to be used in the diagnosis of nitrogen status in jambu leaves.
\end{abstract}

Keywords: Acmella oleracea (L.), Leafy Vegetable, Nutrient Management, SPAD index, Nitrogen Status

\title{
1. Introduction
}

Belonging to Asteraceae family, the jambu (Acmella oleracea (L.) R.K Jansen) it is considered a leafy vegetables of significant importance at the regions that compose the Brazilian Amazon, mainly the Pará State, and is gaining importance in national and international scale due to your peculiar properties, as the momentary anesthesic sensation, due to the bioactive compound named spilanthol whose has been a target of many patents to the production of products for both the pharmaceutical and cosmetics industry (Gusmão \& Gusmão, 2013). 
Albeit, there are challenges in relation of jambu cultivation, once that the technical information about your management are scarce, mainly to nutritional aspect (Sampaio et al., 2018). In this sense, the nitrogen $(\mathrm{N})$ stands out, once that it possesses relation with the production increase and the quality of leafy vegetables (Filgueira, 2013). This is due to the nutrient be found in many organics compounds from the plants, as the amino acids and nucleic acids (DNA and RNA), being a core element at chlorophyll biosynthesis, which involves the photosynthesis directly. Therewithal, it's participated of many physiologic processes of vegetable circle of life, as well as the elements absorption, cellular breathing, multiplication and differentiation (Taiz et al., 2017).

Research with many cultures has been revealed that the increase on $\mathrm{N}$ availability in plants promote higher productivity and quality (Milhomens et al., 2015; Rós et al., 2016). Studies with jambu culture (Borges et al., 2013; Rodrigues et al., 2014; Souto et al., 2018) shown favourable response to nitrogen supplementation through soil, demonstrating high demand of $\mathrm{N}$ to production maintenance and quality. Although studies with jambu, linking the variation in $\mathrm{N}$ supply with the production of dry mass at the aerial and inflorescence part on systems more technics, as in hydroponics, which use nutritive solution instead of soil (Khan et al., 2018), are inexistent. For this reason, independent of the production system, the monitoring of $\mathrm{N}$ contents become indispensable. However, the determination of $\mathrm{N}$ predominantly occurs by laboratory methods which, although accurate, are destructive, time-consuming and relatively costly (Lee et al., 2019).

In this regard, the monitoring of $\mathrm{N}$ content in the plants through the SPAD index has been largely used in many cultures for being a cheap method, fast and non-invasive (Lee et al., 2019; Mendonza-Tafolla et al., 2019). The SPAD index indirectly quantifies the chlorophyll contents in leaves in loco (Milagres et al., 2019). Studies have demonstrated that SPAD units possess direct relation with $\mathrm{N}$ and chlorophyll contents in leaves of vegetables cultures, as potato (Coelho et al., 2012), the zucchini (Pôrto et al., 2011) and the lettuce (Mendonza-Tafolla et al., 2019). Thus, proving that the $\mathrm{N}$ content has been estimated by SPAD units in plants (Lee et al., 2019; Mendonza-Tafolla et al., 2019), it is proposed as a primary hypothesis that the SPAD index can be a value that evaluates the status of $\mathrm{N}$ in jambu leaves. Therefore, it was aimed to evaluate the efficiency of the SPAD index to estimate the $\mathrm{N}$ content in jambu leaves, the total chlorophyll contents, as well as its relation with the dry mass accumulation as a function of the increased $\mathrm{N}$ concentration in the nutritive solution.

\section{Materials and Methods}

\subsection{Experimental Area}

The experiment was conducted at the green house, located at the Soil Science Area of the Agricultural Sciences Institute of Federal Rural University of Amazon, Belém campus. The region weather is classified as Afi according to Köppen classification (Alvares et al., 2013).

During the execution of the experiment the temperature and humidity were determined daily 
through hygrometer term installed in the green house. The averages markings obtained showed averages of $35.3{ }^{\circ} \mathrm{C}$ and $28.1{ }^{\circ} \mathrm{C}$ as maximum and minimum, respectively, the average humidity during the period was $77.1 \%$.

\subsection{Seedling Production}

It was used the variety yellow flower of the jambu (A. oleracea) (Gusmão \& Gusmão, 2013), which was obtained in the active germplasm database of the Federal Rural University of Amazon, Belém campus, in the horticulture sector of the Agrarian Sciences Institute (ASI).

The seedlings were produced in polystyrene trays of 128 cells filled with coconut powder substrate, and then the seeds were sown at a density of six to eight seeds per cell. After the germination, the trays were transferred to benches, where they were watered with nutritive solution proposed by Hoagland \& Arnon (1950) in 25\% of ionic force every two days. With seven days after the germination it was made the thinning, leaving one plant per cell.

With 21 days after the germination, it was made the transplantation to vases filled with sterile ground silica. After the transplantation, the jambu plants went through a seven-day period of acclimatization to the hydroponic system, receiving as source of water and nutrients, the solution of Hoagland \& Arnon (1950), in half of ionic force. After this period, the plants were submitted to your respective treatments. The experimental units consisted in plastic vases with $2 \mathrm{~L}$ of capacity containing one seedling of jambu.

\subsection{Experimental Design and Nutritive Solutions}

The experimental design adopted was of completely randomized, composed of six concentrations of $\mathrm{N}$ in the nutritive solution $\left(11,13,15,17,19\right.$ and $21 \mathrm{mmol} \mathrm{L}^{-1}$ ) with eight repetitions. It has been used the standard solution 2 of Hoagland \& Arnon (1950) which contains $15 \mathrm{mmol} \mathrm{L}^{-1}$, where the compositions of each treatment presented in table 1 .

Table 1. Composition of nutritive solutions $\left(\mathrm{ml} \mathrm{L}^{-1}\right)$ used to prepare the treatments

\begin{tabular}{ccccccc}
\hline Stock Solution & \multicolumn{7}{c}{ Treatments $\left(\mathrm{mmol} \mathrm{L}^{-1}\right)$} \\
\cline { 2 - 7 }$(1 \mathrm{M})$ & 11 & 13 & 15 & 17 & 19 & 21 \\
\hline $\mathrm{NH}_{4} \mathrm{H}_{2} \mathrm{PO}_{4}$ & 1 & 1 & 1 & 1 & 1 & 1 \\
$\mathrm{KNO}_{3}$ & 2 & 4 & 6 & 6 & 6 & 6 \\
$\mathrm{Ca}\left(\mathrm{NO}_{3}\right)_{2}$ & 4 & 4 & 4 & 4 & 5 & 4 \\
$\mathrm{MgSO}_{4}$ & 2 & 2 & 2 & 2 & 2 & 2 \\
$\mathrm{KCl}$ & 4 & 2 & - & - & - & - \\
$\mathrm{NaNO}_{3}$ & - & - & - & - & 2 & 4 \\
$\mathrm{NH}_{4} \mathrm{NO}_{3}$ & - & - & - & 1 & 1 & 1 \\
$\mathrm{Micro}^{1}$ & 1 & 1 & 1 & 1 & 1 & 1 \\
Fe-EDTA $^{2}$ & 1 & 1 & 1 & 1 & 1 & 1 \\
\hline
\end{tabular}


${ }^{1}$ Stock solution of Micronutrients: $2.86 \mathrm{~g} \mathrm{~L}^{-1}$ of $\mathrm{H}_{3} \mathrm{BO}_{3}, 1.81 \mathrm{~g} \mathrm{~L}^{-1}$ of $\mathrm{MnCl}_{2} .4 \mathrm{H}_{2} \mathrm{O}, 0.22 \mathrm{~g} \mathrm{~L}^{-1}$ of $\mathrm{ZnSO}_{4} .5 \mathrm{H}_{2} \mathrm{O}, 0.08 \mathrm{~g} \mathrm{~L}^{-1}$ of $\mathrm{CuSO}_{4} .5 \mathrm{H}_{2} \mathrm{O}$, and $0.02 \mathrm{~g} \mathrm{~L}^{-1}$ of $\mathrm{H}_{2} \mathrm{MoO}_{4} . \mathrm{H}_{2} \mathrm{O}$.

${ }^{2}$ Fe-EDTA: $21.6 \mathrm{~g} \mathrm{~L}^{-1}$ of EDTA, $286 \mathrm{ml} \mathrm{L}^{-1}$ of $\mathrm{KOH} 1 \mathrm{M}$ and $24.9 \mathrm{~g} \mathrm{~L}^{-1} \mathrm{FeSO}_{4} .7 \mathrm{H}_{2} \mathrm{O}$.

During the experiment, the nutritive solutions were oxygenated, through the drainage of the solution at the afternoons end and reposition at the beginning of morning, this procedure was made daily. The solutions were renewed weekly. The $\mathrm{pH}$ of the solutions was daily monitored through the use of a pocket PH-meter model GroLine - HI98118 from HANNA company and maintained in range of 5.5 to 6.5 . When necessary, it was made the correction, by using a solution of $\mathrm{NaOH} 1 \mathrm{~N}$ or with citric acid $\left(\mathrm{C}_{6} \mathrm{H}_{8} \mathrm{O}_{7}\right) 1 \mathrm{~N}$. In addition, the evaporated water was daily replaced, by the use of distilled water.

\subsection{Evaluated Parameters}

\subsubsection{SPAD Index Readings and Total Chlorophyll Content}

After 21 days of the transplantation, occasion that the plants were in the beginning of flowering phase, between 7 and 9 A.M, it was made the measurement of SPAD index, using the portable chlorophilometer 502 from Minolta company. The measurements were made in the second pair of leaves of the main stem from the apex, measuring 20 readings in long of the leaf, avoiding the central rib, and the average of the readings represented the repetition. Following, were collected and stored to total chlorophyll quantification.

To the determination of total chlorophyll, it was performed the homogenization in the dark of 0,1 of leaf tissue in in mortar with $5 \mathrm{ml}$ of $80 \%$ acetone, the extract obtained in this process being filtered into $25 \mathrm{ml}$ volumetric flasks, the volume of the flask being completed by the addition of $20 \mathrm{ml}$ of $80 \%$ acetone. Right after, the pigments were quantified using a spectrophotometer (Femto, model $700 \mathrm{~S}$ ), according to the methodology of Lichthenthaler (1987). The results were expressed on the basis of fresh matter mass ( $\left.\mathrm{mg} \mathrm{g}^{-1} \mathrm{MF}\right)$.

\subsubsection{Leaf Dry Mass}

To determine the dry mass accumulation of the leaves, the seedlings were removed from the pots and separated into aerial part and roots. Then, the leaves of the plants were washed with deionized water and dried with paper towels. From there they were placed in paper bags and then taken to the greenhouse at $65 \pm 5^{\circ} \mathrm{C}$ for about 72 hours, when the plants achieved constant weight. After that, the dry material weighed on a precision scale $(0.001 \mathrm{~g})$.

\subsubsection{Total $\mathrm{N}$ and $\mathrm{N}$ Accumulation}

The leaf samples were crushed in a Wiley type mill, passed through a 20 mesh sieve and stored in paper bags to determine the total nitrogen content according to Silva (2009). The accumulation of $\mathrm{N}$ was performed based on the product calculation of the dry mass of the sheets and the $\mathrm{N}$ content in the jambu sheets.

\subsection{Statistical Analysis}

The data were submitted to variance analysis by the F test at $5 \%$ of probability and, when it's 


\section{1) Macrothink}

Journal of Agricultural Studies

ISSN 2166-0379

2020, Vol. 8, No. 2

significant, it was adjusted the regression models to $\mathrm{N}$ concentrations in the nutritive solution, being the model and your coefficients tested by the ' $t$-student' test. It was conducted the study of correlation between the SPAD index and others analyzed variables as well. The analysis were made through the statistical program SAS (SAS Institute, 2001).

\section{Results and Discussion}

The increase in $\mathrm{N}$ concentration in the nutrient solution influenced $(\mathrm{p}<0.05)$ the dry mass of the leaf, the N content and accumulation, the SPAD index and the total chlorophyll content. In addition, the responses to $\mathrm{N}$ concentration in the solution were adjusted to a positive linear model.

\subsection{Leaf Dry Mass}

The leaves dry mass increased linearly with the elevation of $\mathrm{N}$ concentration in the nutritive solution. The largest accumulation of dry mass was observed in the largest $\mathrm{N}$ concentration (21 mmol L-1) (Figure 1).

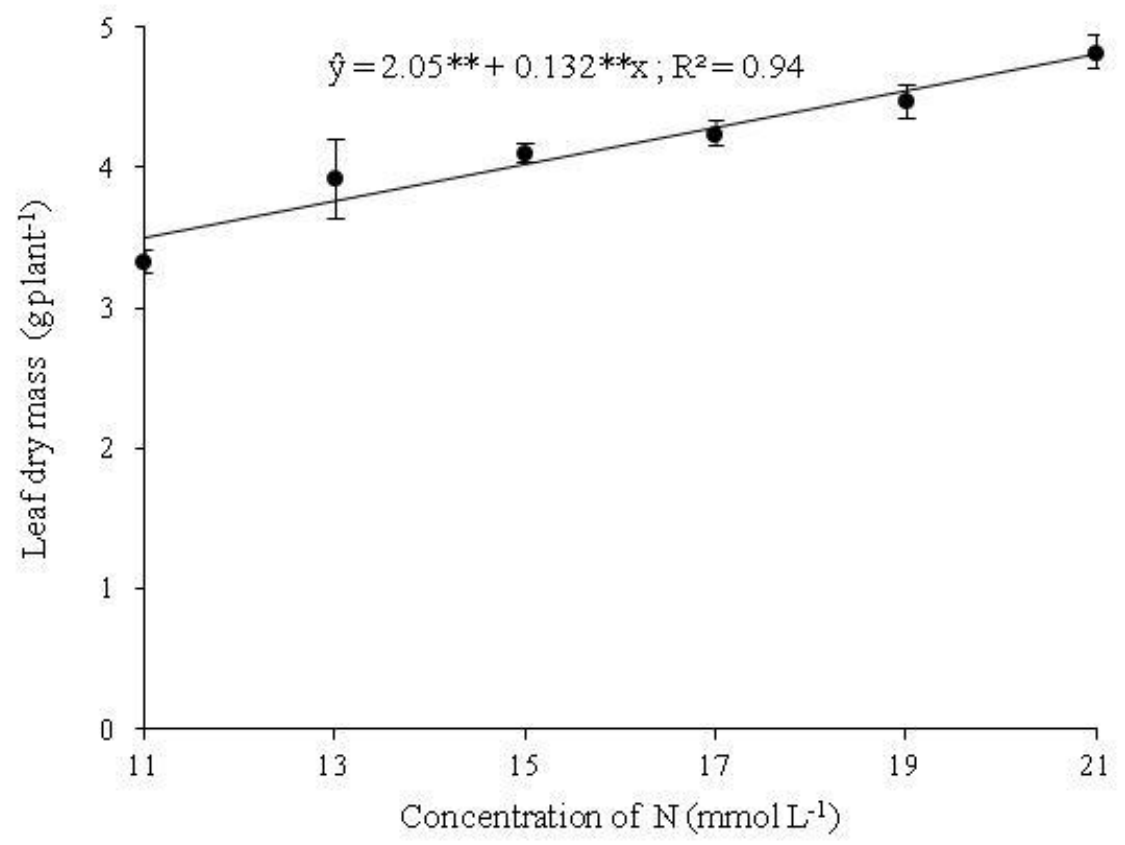

Figure 1. Leaf dry mass of jambu in function of the increase of the nitrogen concentration in nutritive solution $* *$ significant in $1 \%$ of probability; $*$ significant in $5 \%$ of probability through $\mathrm{t}$ test

The $\mathrm{N}$ are related to various plant physiological process, acting in significant manner at the photosynthesis, respiration, ionic absorption and other process related to growing and development vegetal (Mahlangu et al., 2016; Marschner, 2012; Taiz et al., 2017). In general, vegetables have large necessity of $\mathrm{N}$ due to your short cycle, as demonstrated in lettuce studies, jambu same family specie (Mahlangu et al., 2016).

Results from researches have revealed that the increase of $\mathrm{N}$ disponibility to plants promote 


\section{Macrothink}

more accumulation of biomass (Milhomens et al., 2015; Rós et al., 2016). To jambu, Borges et al. (2013) and Rodrigues et al. (2014) observed significant answers at the production, in function of the increase of nitrogen fertilization in soil. In this context, the linear increase of biomass production suggests that the specie can still respond to higher concentrations of this nutrient in nutritive solution, which indicates high responsiveness from plant to element.

\subsection{Total $N$ Content and $N$ accumulation in Leave}

About the level and accumulation of $\mathrm{N}$, it was verified that both adjusted to a linear positive model in function of $\mathrm{N}$ concentration increase in the nutritive solution. As the concentration of $\mathrm{N}$ was elevated in the nutritive solution, there was an increase in $\mathrm{N}$ levels in the jambu leaves, with the maximum level being $\left(43.7 \mathrm{~g} \mathrm{~kg}^{-1}\right)$ determined in concentration of $21 \mathrm{mmol}$ $\mathrm{L}^{-1}$. To the $\mathrm{N}$ accumulation variable, as observed to leaf dry mass accumulation (Figure 1), it was noted an increase in the $\mathrm{N}$ accumulation rates as the $\mathrm{N}$ concentration in solution increased, observing the order variation from 99.1 to $211.6 \mathrm{mg} \mathrm{plant}^{-1}$ in relation to minor (11 $\left.\mathrm{mmol} \mathrm{L}^{-1}\right)$ to the larger dose of $\mathrm{N}\left(21 \mathrm{mmol} \mathrm{L}^{-1}\right)$, respectively (Figure $2 \mathrm{~A}$ and $2 \mathrm{~B}$ ).
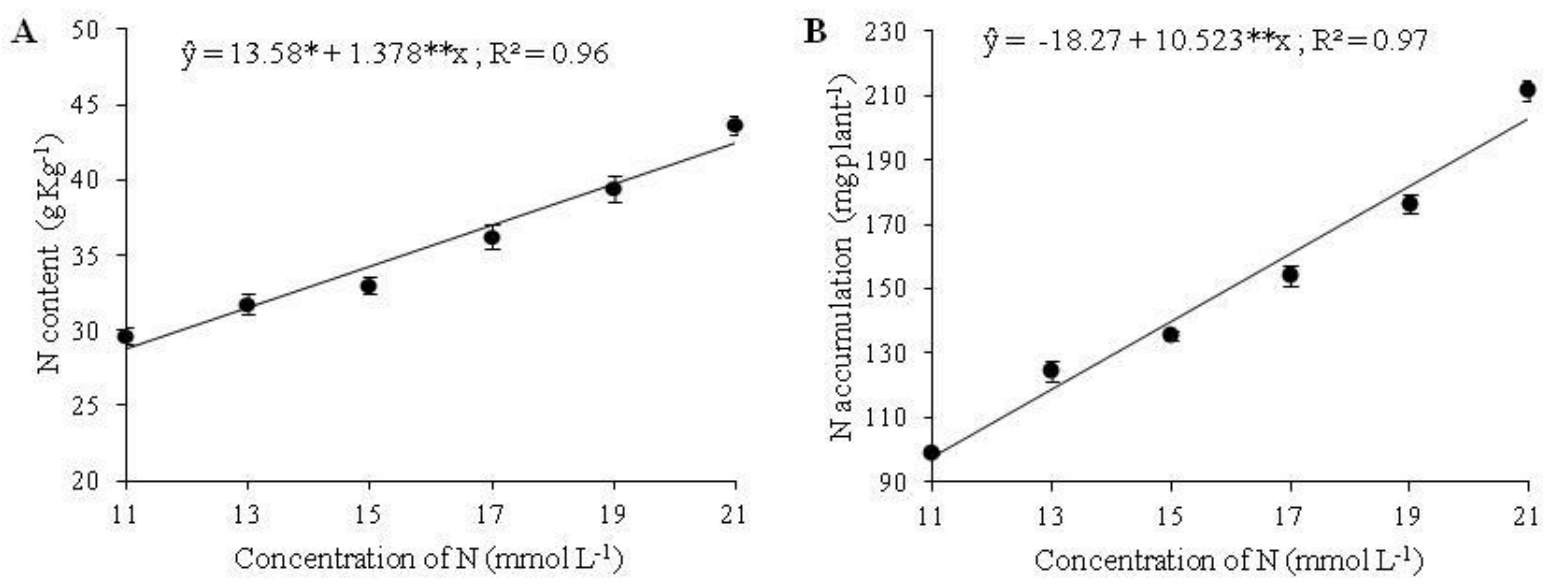

Figure 2. Content (A) and $\mathrm{N}$ accumulation (B) in jambu leaves in function of the increase of nitrogen concentration in the nutritive solution $* *$ significant to $1 \%$ of probability; * significant to $5 \%$ of probability by t test

It was verified, also, the concentrations below of $15 \mathrm{mmol} \mathrm{L}^{-1}$, the leaves have expressed generalized chlorosis, becoming yellowish green, first on the older leaves (Figure 3) and then on all the leaves of the plant. 


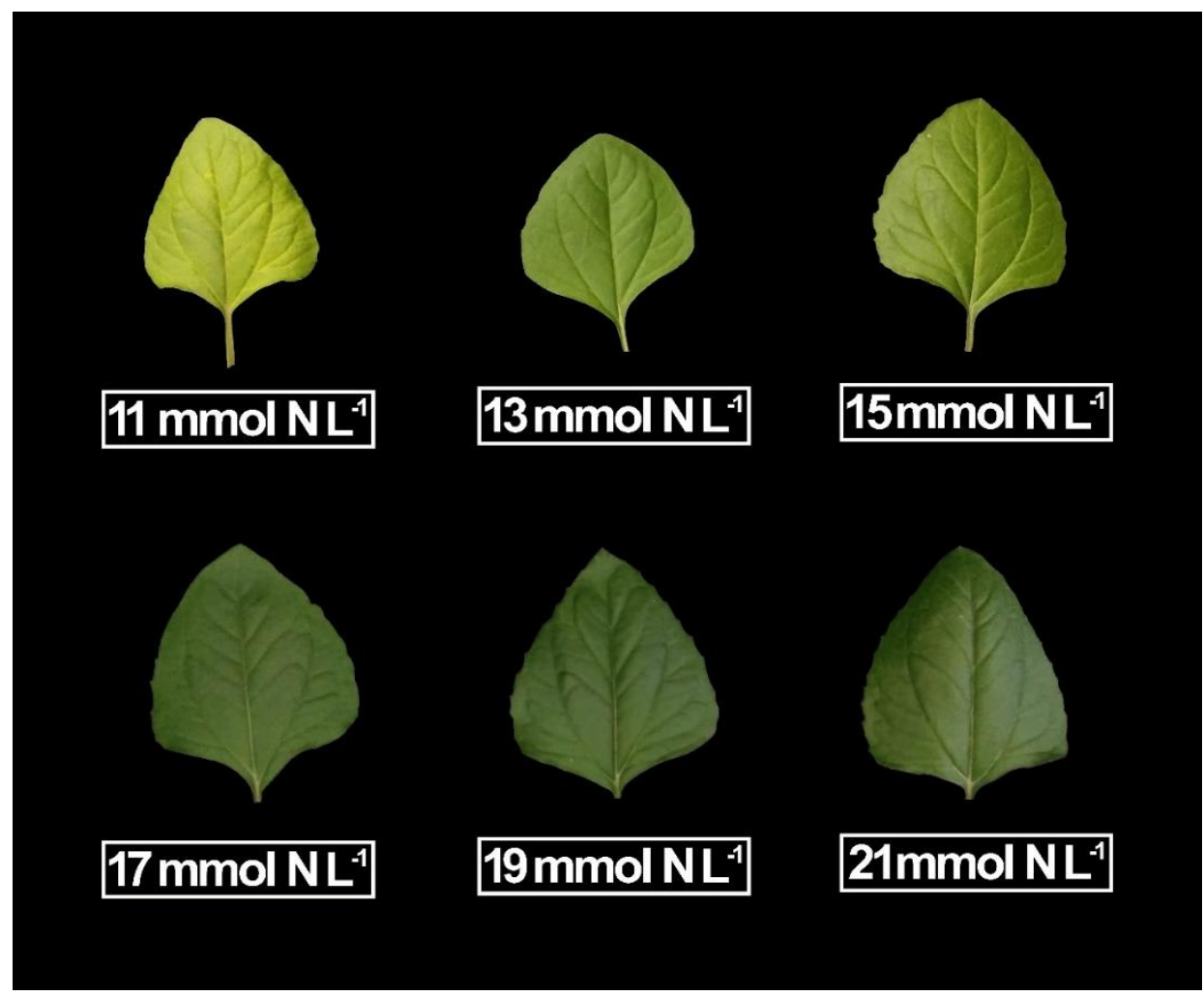

Figure 3. Jambu leaf pigmentation levels taken of the second pair of leaves from the apex to basis of the main stem at the end of the vegetative phase

This fact is due to $\mathrm{N}$ be a nutrient that possess high mobility in the plant phloem and, when in deficiency, is easily redistributed from the oldest leaves to the newest leaves, which are beginning their metabolic process (Marschner, 2012). It is also observed in the figure 3, a pigmentation gradient, as the concentration of $\mathrm{N}$ in the nutritive solution has increased, which indicates that in concentrations under $210 \mathrm{mg} \mathrm{L}^{-1}\left(15 \mathrm{mmol} \mathrm{L}^{-1}\right)$ in the nutritive solution will occur $\mathrm{N}$ deficiency in the plants. Such hypothesis is not only sustained by symptom manifestation itself, as well as the differences in the levels and accumulation of $\mathrm{N}$ in the leaves (Figures 2A and 2B), as the dry mass accumulation (Figure 1), which obtained significant decrease in compare of $15 \mathrm{mmol} \mathrm{L}^{-1}$ concentrations.

Similarly with the symptoms found on this work, Peçanha et al. (2019), working with omission of macro and micro nutrients in jambu plants in nutritive solution, observed generalized chlorosis in old leaves of that vegetable, in addition to significant reductions in the inflorescence numbers, leaves number, leaf area and root dry mass, presenting average levels of $\mathrm{N}$ in the leaves of $26.6 \mathrm{~g} \mathrm{~kg}^{-1}$, values close to those found in these study to $11 \mathrm{mmol}$ $\mathrm{L}^{-1}\left(29 \mathrm{~g} \mathrm{~kg}^{-1}\right)$ concentrations.

The relation of nitrogen fertilization and the $\mathrm{N}$ accumulation in jambu plants was demonstrated for Borges et al. (2013), where it was observed increasing of $\mathrm{N}$ accumulation when it was elevated the doses of urea in soil. In vegetables, $\mathrm{N}$ supports the vegetative development, resulting in leaf area expansion, in addition of influence the productive potential (Filgueira, 2013). 


\subsection{SPAD Index and Total Chlorophyll}

Regarding the SPAD values, obtained in function of the total chlorophyll concentration in the jambu leaves (Figure 4A and 4B), similar to that observed for the other variables, it was verified that there was a linear increase with the elevation of $\mathrm{N}$ concentration in nutritive solution.
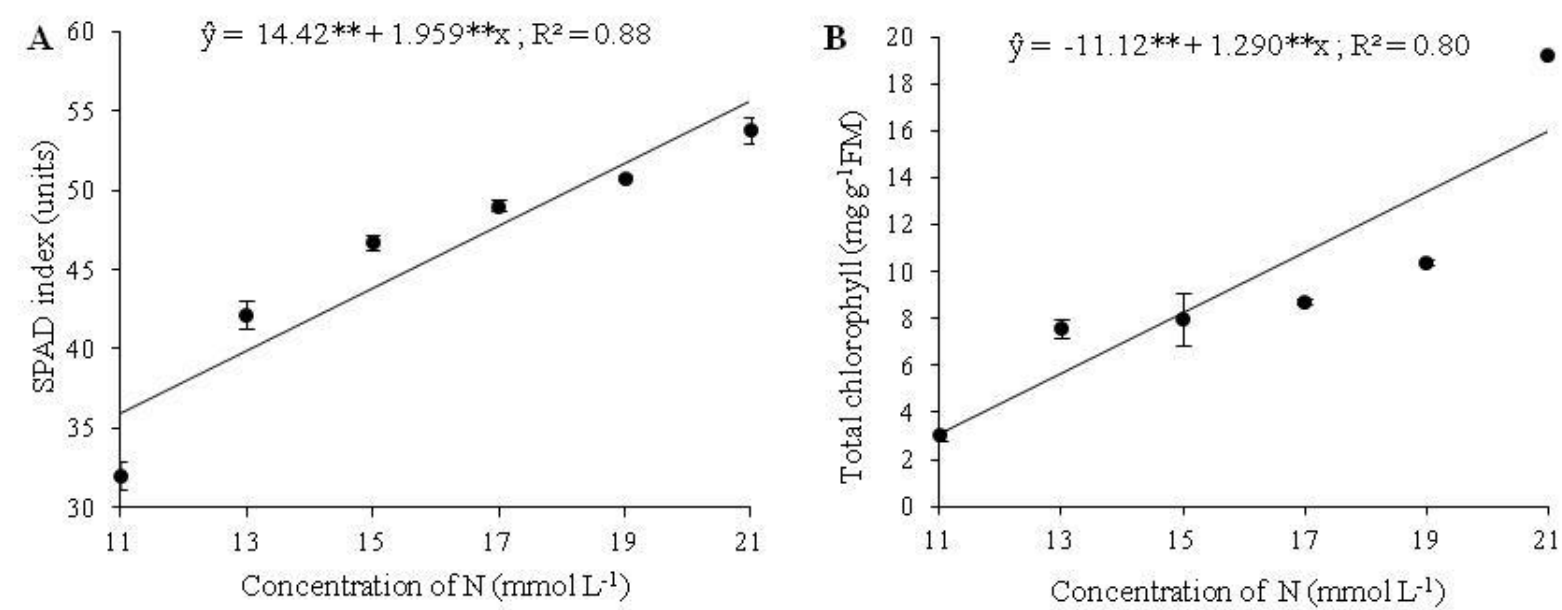

Figure 4. SPAD index (A) and total chlorophyll content (B) of jambu plants as a function of increased nitrogen concentration in the nutrient solution. ** significant at $1 \%$ probability; * significant at $5 \%$ probability by t-test

The SPAD index varied from 32 to 54 units. When comparing the lower concentration of $\mathrm{N}$ $\left(11 \mathrm{mmol} \mathrm{L}^{-1}\right)$ with the higher concentration $\left(21 \mathrm{mmol} \mathrm{L}^{-1}\right)$ it can be seen that the increase in $\mathrm{N}$ supply promoted an increase of approximately $69 \%$ in SPAD units (Figure 4A). Similarly, the total chlorophyll content varied with respect to the lower $\left(11 \mathrm{mmol} \mathrm{L}^{-1}\right)$ and the higher $\mathrm{N}$ dose $\left(21 \mathrm{mmol} \mathrm{L}^{-1}\right)$, and plants submitted to higher concentrations had higher total chlorophyll content (Figure 4B), a result that indicates the potential of the chlorophyll meter in determining the chlorophyll and total $\mathrm{N}$ contents in jambu leaves.

The leaf is the organ in which a large amount of nitrogen compounds, such as proteins and pigments, are concentrated, like chlorophyll (Taiz et al., 2017). Thus, early diagnosis, in real time, provided by the SPAD values, is important, because it enables the decision on adjustments as the application of $\mathrm{N}$ both via soil and in the nutritive solution, reducing the probability of compromising production (Milagres et al., 2018).

Moreover, the results for the adopted cultivation system suggest that values below 46 SPAD units indicate total chlorophyll and $\mathrm{N}$ levels below the ideal for the culture, thus allowing the detection of nitrogen deficiency in jambu leaves (Figure 3). In research developed by Pôrto et al. (2014), involving nitrogen fertilization in tomatoes, it was noted a trend of linear increase in the SPAD index as a function of the $\mathrm{N}$ doses applied. Other studies present results similar to those obtained in this research for this variable, in some crops, such as lettuce (Mendonza-Tafolla et al., 2019) and kaki (Choi et al., 2011) and potato (Coelho et al., 2012).

Mampholo et al. (2018), when working with two lettuce cultivars, observed that the total 
chlorophyll content in the leaves of these vegetable crops increased as the $\mathrm{N}$ supply in the soil increased. This is due to the structural function of $\mathrm{N}$, which is required for the synthesis of chlorophyll molecules; therefore, larger supplies of $\mathrm{N}$ favor the production of chlorophylls (Lee et al., 2019).

3.4 Correlation of the SPAD index, leaf dry mass, total Chlorophyll, $N$ content and $N$ Acumulation

In relation between the SPAD unit values and others variables, it was observed positive significant correlation (Figure 5).
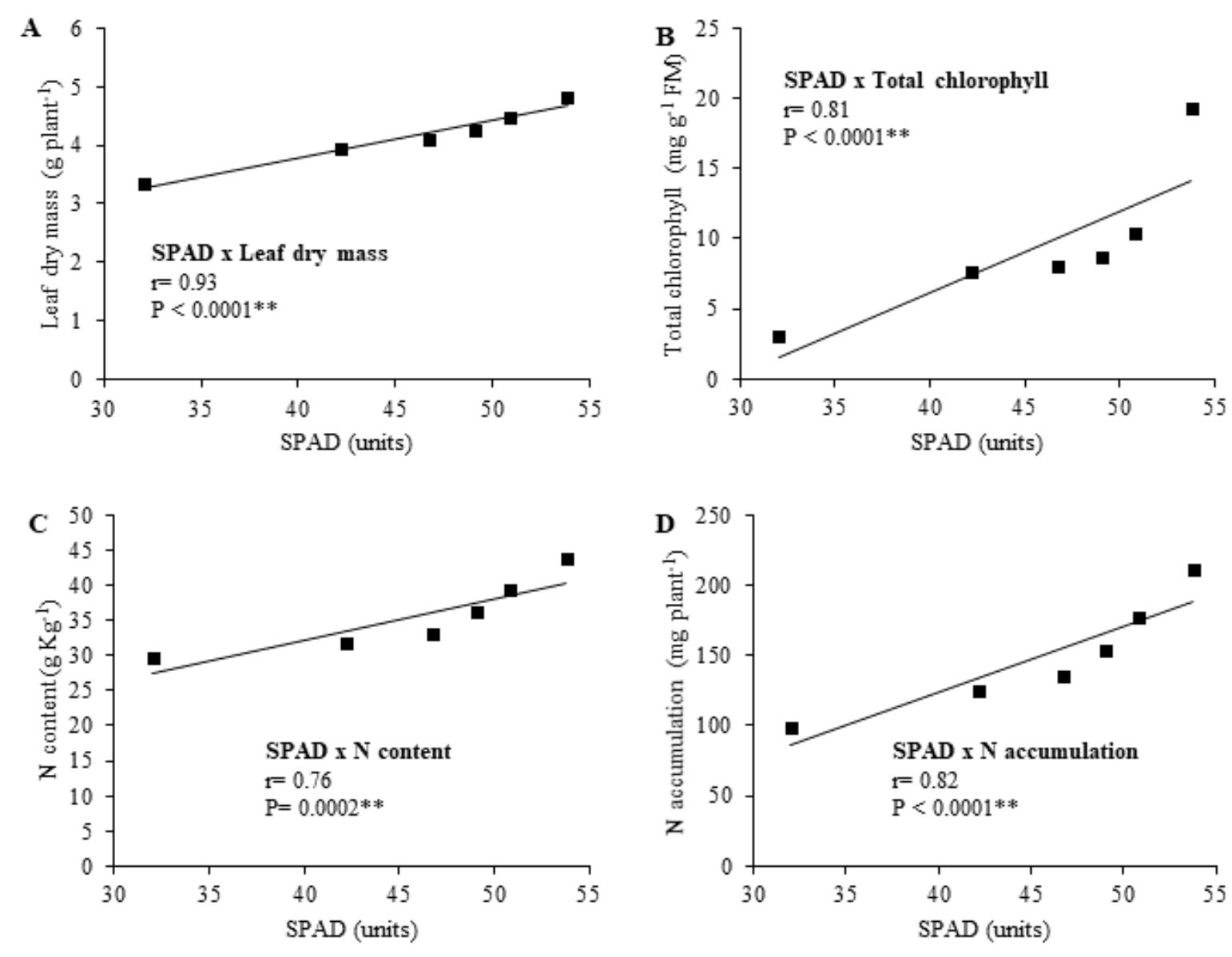

Figure 5. Pearson correlation between SPAD indices and leaf dry mass (A), total chlorophyll (B), $\mathrm{N}$ content (C) and $\mathrm{N}$ accumulation (D). ** Significant at $1 \%$ of probability by t test

It was observed high linear positive correlation $(r=0.93)$ between the variables of leaf dry mass an SPAD units (Figure 5A). Madakadze et al. (1999), observed a positive correlation between SPAD units and leaf dry mass accumulation in Panicum virgatum, thus demonstrating the potential of SPAD units to determine leaf dry mass accumulation.

For total chlorophyll, there was a strong correlation with SPAD units $(r=0.81)$ (Figure 5B). This proves the efficiency of measuring total chlorophyll using a SPAD chlorophyll meter in estimating the chlorophyll content of leaves. Results reported by Mendoza-Tafolla et al. 
(2019) working with lettuce observed a correlation between SPAD units and the chlorophyll content in the leaves of this species.

The association between total chlorophyll content and dry mass accumulation occurs due to the role of chlorophyll in photosynthesis; thus, the higher the chlorophyll index the greater the capacity of the plant to perform photosynthesis and, consequently, higher biomass production (Taiz et al., 2017), as observed by Shadchina \& Dmitrieva (1995), which showed a correlation between the chlorophyll content in the leaves and the dry matter of wheat plants.

The $\mathrm{N}$ content in the leaf presented a positive correlation with SPAD units $(\mathrm{r}=0.76)$, with the highest value obtained (58 units) coinciding with the highest $\mathrm{N}$ content ( $43.7 \mathrm{~g} \mathrm{~kg}^{-1}$ ) (Figure 5C). Since $\mathrm{N}$ is an important component of the chlorophyll molecule, the lack of this element causes a decrease in the green intensity of the leaves of the plants, interfering in the process of photosynthesis, being characterized by chlorosis (Pôrto et al., 2014), relationships observed in this study, observing characteristic symptoms of $\mathrm{N}$ deficiency in levels below $33.0 \mathrm{~g} \mathrm{~kg}^{-1} \mathrm{~N}$ and $46 \mathrm{SPAD}$ units (Figure 2).

A study by Mendoza-Tafolla et al. (2019) showed a high correlation ( $r=0.95)$ between $\mathrm{N}$ contents in Roman lettuce leaf and SPAD units. In other plant species, high correlation between the two variables was demonstrated, as in oregano ( $r=0.64)$ (Medellín et al., 2016) and kaki ( $\mathrm{r}=0.97$ ) (Choi et al., 2011). In general, these studies proved that SPAD has strong correlations with the $\mathrm{N}$ content in the leaf, which correlated with increased photosynthesis and productivity, as observed by Mahlangu et al. (2016). This reaffirms the efficiency of the SPAD chlorophyll meter for diagnosing the $\mathrm{N}$ level in jambu plants, as well as for predicting yield, as observed by Milagres et al. (2018) in potato cultivation.

For the accumulation of $\mathrm{N}$ high linear correlation with SPAD units was observed $(r=0.82)$. This relationship can be established due to the role played by $\mathrm{N}$ as a structural element, composing amino acids and proteins (Taiz et al., 2017), as well as being directly linked to chlorophyll synthesis, as proven in this study and other studies (Medellín et al., 2016; Mendoza-tafolla et al., 2019). Due to this, when this element is deficient, physiological disorders occur in chloroplasts, causing leaf chlorosis (Taiz et al., 2017). This relationship is mainly due to the fact that more than $70 \%$ of the total $\mathrm{N}$ of the leaves integrate enzymes associated with chloroplasts (Dantas et al., 2012), where the chlorophylls are inserted.

\section{Conclusion}

The $\mathrm{N}$ concentrations in the nutrient solution influence the variables evaluated, and the 21 mmol $\mathrm{L}^{-1}$ concentration of $\mathrm{N}$ promoted the best response. In addition, the SPAD index is indicated to indirectly estimate the chlorophyll content, the $\mathrm{N}$ content and the amount of $\mathrm{N}$ accumulated in jambu leaves.

\section{Acknowledgment}

The Amazon Foundation for the Support of Studies and Research (Fapespa) for granting an academic doctorate, ICAAF No. 009/2017, to the first author. 


\section{References}

Alvares, C. A., Stape, J. L., Sentelhas, P. C., Gonçalves, J. L. M., \& Sparovek, G. (2013). Köppen's climate classification map for Brazil. Meteorologische Zeitschrift, 22(6), 711-728. https://doi.org/10.1127/0941-2948/2013/0507

Borges, L. S., Guerrero, A. C., Goto, R., \& Lima, G. P. P. (2013). Productivity and accumulation of nutrients in plants of jambu, under mineral and organic fertilization. Semina: Ciências Agrárias, 83-94. https://doi.org/10.5433/1679-0359.2013v34n1p83

Choi, S. T., Park, D. S., Kang, S. M., \& Park, S. J. (2011). Use of a chlorophyll meter to diagnose nitrogen status of 'Fuyu'persimmon leaves. HortScience, 46(5), 821-824. https://doi.org/10.21273/HORTSCI.46.5.821

Coelho, F. S., Fontes, P. C. R., Finger, F. L., \& Cecon, P. R. (2012). Evaluation of potato nitrogen status based on polyphenol and chlorophyll leaf content. Pesquisa Agropecuária Brasileira, 47(4), 584-592. https://doi.org/10.1590/S0100-204X2012000400015

Dantas, P. A. S., Souza Júnior, J. O., Gomes, F. P., \& Ribeiro, D. O. (2012). Non destructive estimation of foliar nitrogen in cocoa tree using chlorophyll meter. Revista Brasileira de Fruticultura, 34(3), 669-677. https://doi.org/10.1590/S0100-29452012000300004

Filgueira, F. A. R. New olericulture manual: modern agrotechnology in the production and marketing of vegetables. 412 p. Universidade Federal de Viçosa (UFV), Viçosa, Brasil.

Gusmão, M. T. A., \& Gusmão, S. A. L. (Eds.). (2013). Amazonian Jambu: Acmella oleracea, (L.) RK Jansen: general characteristics, convencional, organic and hydroponic cultivation. 135p. UFRA, Universidade Federal Rural da Amazônia.

Hoagland, D. R., \& Arnon, D. I. (1950). The water-culture method for growing plants without soil. Circular. California agricultural experiment station, 347 (2nd edit).

Khan, F. A., Kurklu, A., Ghafoor, A., Ali, Q., Umair, M., \& Shahzaib. (2018). A review on hydroponic greenhouse cultivation for sustainable agriculture. International Journal of Agriculture, Environment and Food Sciences, 2(2), 59-66. https://doi.org/10.31015/jaefs.18010

Lee, Y., Kweon, H. J., Park, M. Y., \& Lee, D. (2019). Field Assessment of Macronutrients and Nitrogen in Apple Leaves Using a Chlorophyll Meter. HortTechnology, 29(3), 300-307. https://doi.org/10.21273/HORTTECH04217-18

Lichthenthaler, H. K. (1987). Chlorophyll and carotenoids-pigments of photosynthetic biomembranes, In: Colowick, SP., Kaplan, NO (ed): Methods in Enzymology, 148. https://doi.org/10.1016/0076-6879(87)48036-1

Madakadze, I. C., Stewart, K. A., Madakadze, R. M., Peterson, P. R., Coulman, B. E., \& Smith, D. L (1999). Field evaluation of the chlorophyll meter to predict yield and nitrogen concentration of switchgrass. Journal of Plant Nutrition, 22(6), 1001-1010. https://doi.org/10.1080/01904169909365689 
Mahlangu, R. I. S., Maboko, M. M., Sivakumar, D., Soundy, P., \& Jifon, J. (2016). Lettuce (Lactuca sativa L.) growth, yield and quality response to nitrogen fertilization in a non-circulating hydroponic system. Journal of Plant Nutrition,39(12), 1766-1775. https://doi.org/10.1080/01904167.2016.1187739

Mampholo, B. M., Maboko, M., Soundy, P., \& Sivakumar, D. (2019). Postharvest responses of hydroponically grown lettuce varieties to nitrogen application rate. Journal of Integrative Agriculture, 18(10), 2272-2283. https://doi.org/10.1016/S2095-3119(19)62664-X

Marschner, P. (Ed.) (2012). Marschner's mineral nutrition of higher plants. 672 p. Academic press. https://doi.org/10.1016/C2009-0-63043-9

Medellín, L. A. C., Rozo, A. M. B., \& Trujillo, M. M. P. (2016). Ensayo preliminar sobre la utilización de un medidor portátil de clorofila para estimar el nitrógeno foliar en orégano (Origanum vulgare L.). Revista Facultad de Ciencias Básicas, 7(2), 150-165. https://doi.org/10.18359/rfcb.2051

Mendoza-Tafolla, R. O., Juarez-Lopez, P., Ontiveros-Capurata, R. E., Sandoval-Villa, M., Iran, A. T., \& Alejo-Santiago, G. (2019). Estimating Nitrogen and Chlorophyll Status of Romaine Lettuce Using SPAD and at LEAF Readings. Notulae Botanicae Horti Agrobotanici Cluj-Napoca, 47(3), 751-756. https://doi.org/10.15835/nbha47311525

Milagres, C. D. C., Fontes, P. C. R., Silveira, M. V. D., Moreira, M. A., \& Lopes, I. P. D. C. (2018). Nitrogen indexes and model to prognostic the potato tubers production. Revista Ceres, 65(3), 261-270. https://doi.org/10.1590/0034-737x201865030006

Milhomens, K. K. B., Nascimento, I. R., Tavares, R. C., Ferreira, T. A., \& Souza, M. E. (2015). Evaluation of agronomic traits of lettuce cultivars under different nitrogen levels. Revista Verde de Agroecologia e Desenvolvimento Sustentável. https://doi.org/10.18378/rvads.v10i1.2940

Peçanha, D. A., Freitas, M. S. M., Vieira, M. E., Lima, T. C., \& Gonçalves, Y. S. (2019). Characterization of deficiency symptoms and mineral nutrient content in Acmella oleracea cultivated under macronutrient and boron omissions. Journal of Plant Nutrition, 42(8), 879-890. https://doi.org/10.1080/01904167.2019.1584216

Pôrto, M. L. A., Puiatti, M., Fontes, P. C. R., Cecon, P. R., \& Do Carmo Alves, J. (2014). SPAD index for diagnosis of nitrogen status in the Japanese cucumber plants under protected cultivation. Horticultura Brasileira, 32(3), https://doi.org/10.1590/S0102-05362014000300009

Pôrto, M. L., Puiatti, M., Fontes, P. C. R., Cecon, P. R., Alves, J. C., \& Arruda, J. A. (2011). SPAD index for nitrogen status diagnosis of zucchini plants. Horticultura Brasileira, 29(3), 311-315. https://doi.org/10.1590/S0102-05362011000300009

Rodrigues, D. S., Camargo, M. S., Nomura, E. S., Garcia, V. A., Correa, J. N., \& Vidal, T. C. M. (2014). Influence of the fertilization with nitrogen and phosphorus in the production of 
jambu (Acmella oleracea (L) R.K. Jansen). Revista Brasileira de Plantas Medicinais, 71-76. https://doi.org/10.1590/S1516-05722014000100010

Rós, A. B., Narita, N., \& Reis, A. S. (2016). Production of sweet potato branches in suspended pots depending on nitrogen fertilization. Científica,44(2), 170-175. https://doi.org/10.15361/1984-5529.2016v44n2p170-175

Sampaio, I. M. G., Guimarães, M. A., Neto, H. D. S. L., Maia, C. L., Viana, C. S., \& Gusmão, S. A. L. (2018). Could the use of grouped seedlings and increased sowing density lead to higher yield of jambu? Revista de Ciências Agrárias Amazonian Journal of Agricultural and Environmental Sciences, 61. https://doi.org/10.22491/rca.2018.2906

SAS, S. (2002). STATUsersGuide for Personal Computers. Release, 6, 12.

Shadchina, T. M., \& Dmitrieva, V. V. (1995). Leaf chlorophyll content as a possible diagnostic mean for the evaluation of plant nitrogen uptake from the soil. Journal of Plant Nutrition, 18(7), 1427-1437. https://doi.org/10.1080/01904169509364992

Silva, F. C. D. S. (Ed.). (2009). Manual of chemical analysis of soils, plants and fertilizers. 627 p. Embrapa Solos.

Souto, G. C., Grangeiro, L. C., Gusmão, S. A. L., Sousa, V. F. L., Cavalcante, A. E. C., \& França, F. D. (2018). Agronomic performance of jambu (Acmella oleracea) using organic fertilization. Australian Journal of Crop $\quad$ Science, 12(1), 151. https://doi.org/10.21475/ajcs.18.12.01.pne819

Taiz, L., Zeiger, E., Moller, I., \& Murphy, A. (2017). Plant physiology and development. 888p. Artmed Editora.

\section{Glossary}

AAB Device: an equipment for sky.

KKD Device: an equipment for shipping.

\section{Appendix}

Appendix 1. Survey Question for Mobilephone Marketing

Appendix 2. Model of Population

\section{Copyright Disclaimer}

Copyright for this article is retained by the author(s), with first publication rights granted to the journal.

This is an open-access article distributed under the terms and conditions of the Creative Commons Attribution license (http://creativecommons.org/licenses/by/4.0/). 